Available online at http://jddtonline.info

RESEARCH ARTICLE

\title{
EVALUATION OF ANTIHYPERLIPIDAEMIC EFFECT OF CEDRELA TOONA ROXB. FRUITS
}

\author{
Shah Kinjal $\mathbf{H}^{\mathbf{1}^{*}}$, Dr. Patel Piyush $\mathbf{M}^{2}$ \\ ${ }^{1}$ Research Scholar, Singhania University, Pacheri Bari, Jhunjunu, Rajasthan, India \\ ${ }^{2}$ Professor, Shri B. M. Shah College Of Pharmaceutical Education And Research, Modasa, Gujarat, India \\ *Correspondent Author's E-mail: kinjalhshah9@yahooo.co.in
}

Received 21 Oct 2012; Review Completed 07 Nov 2012; Accepted 09 Nov 2012, Available online 15 Nov 2012

\begin{abstract}
Fruit extracts of Cedrela toona Roxb. were evaluated for their antihyperlipidaemic effect in swiss albino female rats. High Cholesterol diet was prepared by mixing cholesterol $2 \%$, sodium cholate $1 \%$ and coconut oil $2 \%$ or $30 \%$, with standard powdered standard animal food. The diet was placed in the cage carefully and was aministered for seven days. Methanol, Chloroform, and Aqueous extracts of Cedrela toona fruits were administered orally at a dose of $250 \mathrm{mg} / \mathrm{kg}$ body wt to Hyperlipidaemic rats. After seven days, blood samples were collected from the tail vein after $8 \mathrm{hr}$ fast and allowed to clot for 30 minutes at room temperature. Blood samples were centrifuged at $3000 \mathrm{rpm}$ for 20 minutes. Serum was separated and stored at $-20^{\circ} \mathrm{C}$ until biochemical estimations were carried out. Serum samples were analyzed spectrophotometrically for Cholesterol, triglyceride and HDL-C was estimated using diagnostic kits which were procured from Lab-Care Diagnostics (India) Pvt. Ltd.- Mumbai (India). Results showed that methanolic extract and aqueous extract had significant effect in hyperlipidemic rats.
\end{abstract}

Keywords: Cedrela toona, Hyperlipidaemia, Fruit, Cholesterol, Triglyceride.

\section{INTRODUCTION}

Litreture survey reveals that Cedrela toona Roxb. is medium sized to large deciduous tree with brown to grey scaly bark. Leaves $15-45 \mathrm{~cm}$ long usually paripinnate but sometimes with a terminal leaflet in juvenile growth, leaflets mostly 8-20, \pm ovate, often falcate, $4-15 \mathrm{~cm}$ long, 15-50 $\mathrm{mm}$ wide, apex acuminate, base strongly asymmetric, margins entire, mostly glabrous, domatia present as small hair - tuffs; petiole $4-11 \mathrm{~cm}$ long, petiolules 5-12 mm long. Penicles $20-40 \mathrm{~cm}$ long. Petals 5-6 mm long, white. Capsule ellipsoid, 10-20 mm long, 6$8 \mathrm{~mm}$ diameter; seeds winged at both ends ${ }^{1,2,3,4}$. Traditionally the bark is astringent, antidysentric, antiperiodic 5 . Flowers are emmenagogue, leaf is spasmolytic, hypoglycaemic and antiprotozoal ${ }^{6}$. Bark and heartwood yielded tetraterpenoids, including toonacillin. Heartwood also gave a coumarin gerarnyl gernalol as its fatty esters. Toonacillin and its 6 - hydroxyl derivatives are antifeedent ${ }^{5}$. It is useful in chronic dysentery, ulcer, leprosy, cures fever, headache, blood complaints (Ayurveda), cardiotonic, aphrodisiac, anthelmentic; good for scabis and expectorant (Yunani) ${ }^{6,7}$

Phytochemical studies reported the presence of Cedrelone , isolated from the benzene extract of the heartwood of the Cedrela toona Roxb ${ }^{9,10}$, sesquiterpene, cycloartene stigmasterol, campesterol, apotirucallene, tirucallene, catechin, proanthocynidin ,leucoanthocyanidin, toonacilin, 6 -acetoxy toonacilin, toonacilid, geranyl geraniol, $\delta$ cadinene, calamenene, $\alpha$-calacorene, siderin, deoxycedrelone ${ }^{18}$. Cedrelone, isolated from the benzenel extract of heartwood of Toona ciliata, on photooxidation yield; $3[14 \beta, 15 \beta, 22 \beta, 23 \beta$-diepoxy-6-hydroxy-6-hydroy$1,5,20(22)$ - meliatriene-2,7,21-trione], along with product $4[14 \beta, 15 \beta$-epoxy-6,23-dihydroxy- 1,5,20(22)-meliatriene$2,7,21$-trione $]^{11}$. $12 \alpha$ - hydroxystigmat-4-en-3-one: a new bioactive steroid isolated from the petroleum ether extract (C) 2011, JDDT. All Rights Reserved of Toona ciliate (Meliaceae) along with the two known steroid and three C- methyl coumarins ${ }^{12}$. 5methylcoumarins isolated from the dried and powdered stem bark of Toona ciliata, extracted successively with light petroleum ether $\left(40-60^{\circ}\right)$, dichloromethane and methanol in soxhlet apparatus ${ }^{13}$. Limonoids i.e.Toonaciliatins were reported from leaves and stem of Toona ciliata $^{14}$. Siderin , a natural coumarin was isolated from the methanolic extract of the leaves of Toona ciliata with the help of column chromatography ${ }^{15}$. Toonafolin , a tetranortriterpenoid Blactone isolated from the ether extract of leaves of Toona ciliata. Polyynes isolated from the ethylacetate extract of the leaves of Toona ciliata ${ }^{16}$. Seven new compounds were isolated from the petrol and chloroform extract of the trees of Toona ciliata, and there structure were identified as 3-Acetoxy 17-furan-3- yl-1hydroxy-1,4,4,10,13-penta-methyl-12-oxo-

tetradecahydro-16,20-

dioxacyclopropa[14,15]cyclopenta[alpha]phenanthrene-7carboxylic acid methyl ester, beta sitosterol, stigmasterol, n-C35H72, palmitinic acid, n-C20H42,3-(3-Propyl$\left\{1,1,3\right.$, 1_]tercyclohexan-3-yl)-propan-1-ol ${ }^{17}$.

9,10 dihydrophenanthrenes isolated from the dichloromethane extract of the root of Toona cilita $^{18}$. One new limonoid, toonaciliatone $\mathrm{A}$, and one new tirucallane type triterpenoid, toonaciliatine $\mathrm{A}$, along with three known compounds, methyl - 3b-acetoxy-1-oxomelic-14(15)enate, perforin $\mathrm{A}$, and cholest-14-ene-3,7,24,25-tetrol21,23-epoxy-21-methoxy-4,4,8-trimethyl-3-(3-methyl-2butenoate), were isolated from the leaves of Toona ciliata $^{19,20}$.

Plant also possess antioxidant ${ }^{21,22}$, Antiulcer $^{23,24}$, Analgesic $^{25}$, Antifungal ${ }^{26}$, Antimicrobial ${ }^{27,28}$, Anti feedant, Anti tumor ${ }^{29}$ activity and cytotoxicity ${ }^{29}$. The present study is designed to explore the anti diabetic effect of various
CODEN (USA): JDDTAO 
extracts of leaves of the plant Cedrela toona Roxb. belonging to Family Meliaceae. The present study is designed to explore the anti hyperlipidaemic effect of various extracts of fruits of the plant Cedrela toona Roxb. belonging to Family Meliaceae.

\section{MATERIAL AND METHODS}

\section{Chemicals}

All the chemicals used were of analytical grade and purchased from the Chemco, Rajkot, Gujarat, India and Sd Fine Chem. Limited Mumbai, India.

\section{Plant collection and identification}

The fruits of the plant were collected from the Paritosh Herbals, Dehradun in the month of October 2011. The plant was identified and authentified as Cedrela toona Roxb. (Family: Meliaceae ) by Dr. M. S. Jangid, Department of Botany at Sir P. T. Science College, Modasa, Gujarat, India where a voucher specimen has been deposited.

\section{Processing of collected plant sample}

The collected plant material was air-dried for two weeks and then powdered using mortar and pestle. The powder obtained was stored in air tight for use in phytochemical analysis and determination of pharmacopoeia standards ${ }^{31}$.

\begin{abstract}
Animals ${ }^{31}$
Swiss albino/Sprague Dawely female rats weighing 150200-250 gm were acclimatized to the experimental room having temperature $23 \pm 2 \square \mathrm{C}$, controlled humidity conditions, and 12:12 hour light and dark cycle. Animals were caged in polypropylene cages in a group with maximum of three animals per cage. The rats were fed with standard food pellets and water ad libitum. The study was approved by Institutional Animal Ethical Committee, B. Pharmacy College, Rampura - Kakanpur, Gujarat, India (IAEC/RAMPH/04/2011-12).
\end{abstract}

\section{Induction of hyperlipdemia ${ }^{32,33}$}

High Cholesterol diet was prepared by mixing cholesterol $2 \%$, sodium cholate $1 \%$ and coconut oil $2 \%$ or $30 \%$, with standard powdered standard animal food. The diet was placed in the cage carefully and was aministered for seven days.

\section{Instruments}

The following instruments were used in the study.

- UV spectrophotometer (Shimadzu 1650 PC)

- Centrifuge (Remi)

- $\quad$ Sonicator (Enertech Lab)

\section{Preparation of the Extracts ${ }^{34}$}

$100 \mathrm{~g}$ of each of air-dried powdered material of leaves, stems and fruits of Cedrela toona Roxb. was successively extracted with the following solvents of increasing polarity in a soxhlet apparatus.

- petroleum ether $\left(60^{\circ}-80^{\circ} \mathrm{c}\right)$

- hexane

- Acetone

- methanol

- distilled water

All the extracts were concentrated by distilling the solvents and the extracts were dried in an oven at $50^{\circ} \mathrm{c}$. Each time before extracting with the next solvent, the marc was dried in an air oven below at $50^{\circ} \mathrm{c}$. The marc was finally macerated with water for 24 hours to obtain the aqueous extract. The completion of the extraction was confirmed by evaporating a few drops of extract from the thimble on watch glass to observe that no residue remained after evaporation of the solvent. The liquid extracts obtained with different solvents were collected. The extracts was dissolved in water by preparing dose of 1 $\mathrm{gm} / \mathrm{kg}$.

\section{Treatment protocol}

The experimental animals were divided into six groups, six animals in each group

Group-1: Normal

Group-2: High cholesterol diet control

Group-3: High cholesterol diet treated with Petroleum ether extract of Cedrela toona Roxb. [1gm/Kg body weigth, p.o.]

Group-4: High cholesterol diet treated with Acetone extract of Cedrela toona Roxb. [1 $\mathrm{gm} / \mathrm{Kg}$ body weigth, p.o.]

Group-5: High cholesterol diet treated with Methanol extract of Cedrela toona Roxb. [1 $\mathrm{gm} / \mathrm{Kg}$ body weigth, p.o.]

Group-6: High cholesterol diet treated with Water extract of Cedrela toona Roxb. [1 gm/Kg body weigth, p.o.]

Treatment was given daily for seven days orally.

Blood sample collection and analysis ${ }^{32,33}$

After seven days, blood samples were collected from the tail vein after $8 \mathrm{hr}$ fast and allowed to clot for 30 minutes at room temperature. Blood samples were centrifuged at $3000 \mathrm{rpm}$ for 20 minutes. Serum was separated and stored at $-20^{\circ} \mathrm{C}$ until biochemical estimations were carried out. Serum samples were analyzed spectrophotometrically for Cholesterol, triglyceride and HDL-C was estimated using diagnostic kits which were procured from Lab-Care Diagnostics (India) Pvt. Ltd.- Mumbai (India). 


\section{Details of Biochemical Parameters Used}

\section{Cholesterol}

Principle

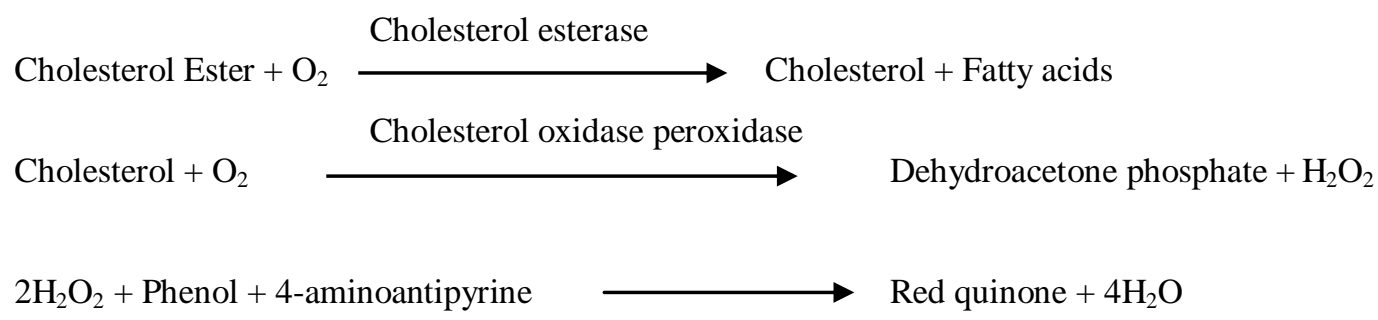

The intensity of the red complex (red quinone) formed during the reaction is directly proportional to the cholesterol concentration in the sample and is measured at 500nm.

\section{$\underline{\text { Procedure }}$}

Reagents were reconstituted as described in the leaflet supplied along with the kit. $10 \mu \mathrm{l}$ of serum samples, distilled water serving as control and standard triglyceride $(200 \mathrm{mg} / \mathrm{dl})$ serving as standard were mixed well with $1.0 \mathrm{ml}$ reconstituted reagent i.e. enzyme/chromogen mixture. They were incubated at $37^{\circ} \mathrm{C}$ for min and absorbance was read against blank at $500 \mathrm{~nm}$.

\section{Calculation}

Serum cholesterol $(\mathrm{mg} / \mathrm{dl})=\frac{\text { O.D. of test }}{\text { O.D. of STD }} \times 200$

\section{Triglyceride}

\section{Principle}

Triglycerides are enzymatically hydrolyzed to glycerol according to the following reactions

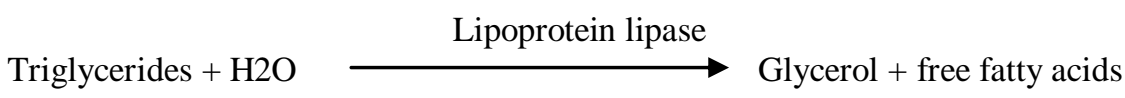

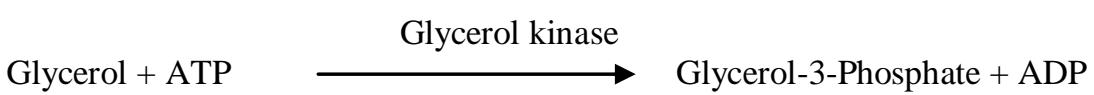

Glycerol-3-Phosphate $+\mathrm{O}_{2} \stackrel{\text { GPO }}{\longrightarrow} \quad$ Dehydroacetone phosphate $+\mathrm{H}_{2} \mathrm{O}_{2}$

$2 \mathrm{H}_{2} \mathrm{O}_{2}+4$-aminoantipyrine + ADPS $\stackrel{\text { Peroxidase }}{\longrightarrow}$ Red quinone $+4 \mathrm{H}_{2} \mathrm{O}$

GPO = Glycerol-3-Phosphate Oxidase

ADPS $=$ N-Ethyl-N-Sulfopropyl-n-anisidine

The intensity of the red complex (red quinone) complex formed during the reaction is directly proportional to the triglyceride concentration in the sample and is measured at $546 \mathrm{~nm}$. The final colour is stable for at least $30 \mathrm{~min}$.

\section{Procedure}

Reagents were reconstituted as described in the leaflet supplied along with the kit. $10 \mu$ of serum samples, distilled water serving as control and standard triglyceride $(200 \mathrm{mg} / \mathrm{dl})$ serving as standard were mixed well with $1.0 \mathrm{ml}$ reconstituted reagent 1 i.e. enzyme/chromogen mixture. They were incubated at $37^{\circ} \mathrm{C}$ for min and absorbance was read against blank at $546 \mathrm{~nm}$.

Calculation O.D. of test

Serum triglyceride $(\mathrm{mg} / \mathrm{dl})=$ 


\section{$\underline{\text { Principle }}$}

Chylomicrons, VLDL, and LDL fractions in serum or plasma are separated from HDL by precipitating with phosphotungstic acid and magnesium chloride. After centrifugation, the cholesterol in HDL fraction, which remains in the supernatant is assayed with enzymatic cholesterol method, using cholesterol esterage, cholesterol oxidase, peroxidase and the chromogen 4-amino antipyrine/phenol.

\section{$\underline{\text { Procedure }}$}

Reagents were reconstituted as described in the leaflet supplied along with the kit. $0.2 \mathrm{ml}$ of serum sample was mixed well with $0.2 \mathrm{ml}$ of precipitating reagent (Reagent 2) and centrifuged at 3500-4000 for $10 \mathrm{~min}$. Supernatant $20 \mu \mathrm{l}$ and $1 \mathrm{ml}$ of reconstituted reagent 1 was added. In case on blank $1 \mathrm{ml}$ reconstituted reagent 1 was taken. Absorbance of test samples was measured against reagent blank at 500nm.

Calculation

$$
\text { Serum HDL-C }(\mathrm{mg} / \mathrm{dl})=\frac{\text { O.D. } \text { of test }}{\text { O.D. of STD }} \times 50 \times 2
$$

VLDL, LDL, HDL-ratio and Atherogenic index were calculated by using the formula as mentioned below:

VLDL-C $=\underline{\text { Total serum triglycerides }}$

$$
5
$$

LDL-C $(\mathrm{mg} / \mathrm{dl})=$ Total serum cholesterol $-\underline{\text { Total serum triglycerides }}$ - HDL-C

HDL ratio $=\underline{\text { HDL-cholesterol } \times 100}$

Total serum cholesterol - HDL-C

$\mathrm{AI}=\quad$ Total serum triglycerides

Total serum HDL-C

\section{Statistical Analysis}

Results are presented as mean \pm SEM of 6 animals. Statistical differences between the means of the various groups were evaluated using one-way analysis of variance (ANOVA) followed by Tukey test. Data were considered statistically significant at $\mathrm{P}$ value $\leq 0.05$.

\section{RESULT AND DISCUSSION}

Effect of one week treatment with different extract at a dose $250 \mathrm{mg} / \mathrm{kg}$ in high cholesterol diet induced hyperlipidaemia in rats. PE: Petroleum Ether Extract, CE : Chloroform Extract, ME : Methanolic Extract, AE : Aqueous Extract

Table 1: Effect of various extracts on LDI, VLDL, HDL - Ratio and Atherogenic Index

\begin{tabular}{|l|l|l|l|l|l|}
\hline Sr. no. & Group & LDL-C & VLDL & HDL-Ratio & Atherogenic Index \\
\hline 1 & Normal & $6.21 \pm 6.57$ & $17.49 \pm 0.49$ & $215.72 \pm 70.51$ & $2.08 \pm 0.10$ \\
\hline 2 & Control & $447.39 \pm 21.66$ & $36.35 \pm 1.29$ & $4.42 \pm 0.35$ & $8.57 \pm 0.09$ \\
\hline 3 & PE & $373.70 \pm 25.86$ & $25.33 \pm 0.54$ & $7.15 \pm 0.47$ & $4.48 \pm 0.18$ \\
\hline 4 & CE & $256.83 \pm 5.53$ & $19.74 \pm 2.73$ & $12.50 \pm 2.43$ & $2.85 \pm 0.67$ \\
\hline 5 & ME & $266.50 \pm 4.98$ & $14.67 \pm 0.88$ & $12.91 \pm 2.43$ & $2.02 \pm 0.43$ \\
\hline 6 & AE & $234.62 \pm 0.15$ & $17.74 \pm 0.49$ & $15.58 \pm 2.16$ & $2.26 \pm 0.54$ \\
\hline
\end{tabular}

Table 2: Effect of various extracts on Serum cholesterol, Triglyceride and HDL - C

\begin{tabular}{|l|l|l|l|l|}
\hline Sr. no. & Group & Serum Cholestrol & Triglyceride & HDL-C \\
\hline 1 & Normal & $65.82 \pm 1.90$ & $87.44 \pm 2.45$ & $42.12 \pm 1.20$ \\
\hline 2 & Control & $378.73 \pm 5.00$ & $181.80 \pm 6.47$ & $21.23 \pm 0.91$ \\
\hline 3 & PE & $320.51 \pm 6.58$ & $126.67 \pm 2.71$ & $33.31 \pm 1.96$ \\
\hline 4 & CE & $311.13 \pm 10.28$ & $98.71 \pm 13.65$ & $34.56 \pm 2.01$ \\
\hline 5 & ME & $317.47 \pm 7.85$ & $73.33 \pm 4.43$ & $36.29 \pm 1.98$ \\
\hline 6 & AE & $291.64 \pm 4.56$ & $88.72 \pm 2.45$ & $39.28 \pm 4.21$ \\
\hline
\end{tabular}




\section{Serum cholesterol (SC)}

High cholesterol diet rats exhibited higher cholesterol levels as compared to normal rats (Fig 1). Treatment with $\mathrm{ME}$ and $\mathrm{AE}$ significantly decreased elevated cholesterol levels in hyperlipidemic rats.

\section{Serum triglyceride}

High cholesterol diet rats exhibited significantly higher triglyceride (Fig 2) levels as compared to normal control rats. Treatment with of $\mathrm{ME}$ and $\mathrm{AE}$ significantly decreased elevated triglyceride levels in hyperlipidemic rats.

\section{Serum HDL-Cholesterol}

High cholesterol diet rats exhibited significantly lower HDL-C (Fig 3) levels as compared to normal control rats. Treatment with ME and AE significantly increased HDL$\mathrm{C}$ levels as compared to high cholesterol diet rats.

\section{Serum LDL}

High cholesterol diet rats exhibited significantly higher LDL (Fig 4) levels as compared to normal control rats. Treatment with ME and AE extract significantly lowered levels of LDL as compared to high cholesterol diet rats.

\section{Serum VLDL}

High cholesterol diet rats exhibited significantly higher VLDL (Fig 5) levels as compared to normal control rats. Treatment with ME and AE significantly lowered levels of VLDL as compared to high cholesterol diet rats.

\section{Atherogenic index and HDL-ratio}

High cholesterol diet rats exhibited significantly higher atherogenic index (Fig 6) and lower the HDL-ratio as compared to control rats. Treatment with $\mathrm{ME}$ and $\mathrm{AE}$ significantly lowered the atherogenic index (Fig 7) and increased HDL-ratio.

Each bar in figure represents Mean \pm S.E.M. number of animals in each group $=6 . \mathrm{R} 1=$ control, $\mathrm{R} 2=$ high cholesterol diet control, R3 = high cholesterol diet treated with Petrolium ether extract of Cedrela toona Roxb. $(1 \mathrm{gm} / \mathrm{kg}$, p.o. $), \mathrm{R} 4=$ high cholesterol diet treated with Chloroform extract of Cedrela toona Roxb. $(1 \mathrm{gm} / \mathrm{kg}$, p.o.), R5 = high cholesterol diet treated with Methanol extract of Cedrela toona Roxb. (1 gm/ $/ \mathrm{kg}$, p.o.), R6 = high cholesterol diet treated with Aqueous extract of Cedrela toona Roxb. (1gm/kg, p.o.) * significantly different from control, ** significantly different from high cholesterol diet control rats, $\mathrm{p}<0.05$.

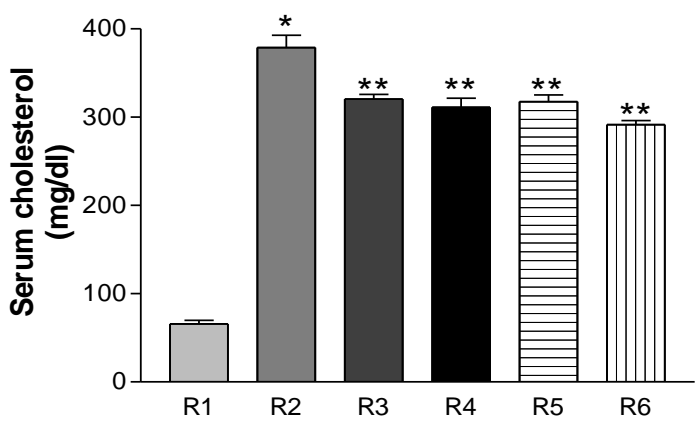

Figure 1: Effect of Various Extracts of Cedrela toona Roxb. On Serum Cholesterol levels

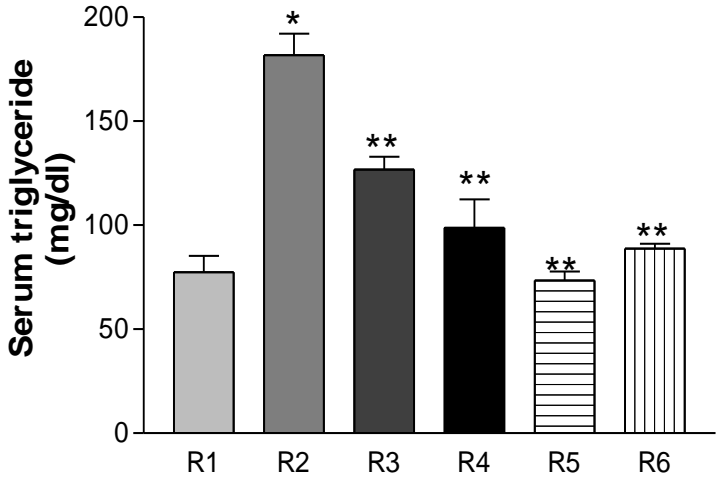

Figure 2: Effect of Various Extracts of Cedrela toona Roxb. On Serum Triglyceride levels

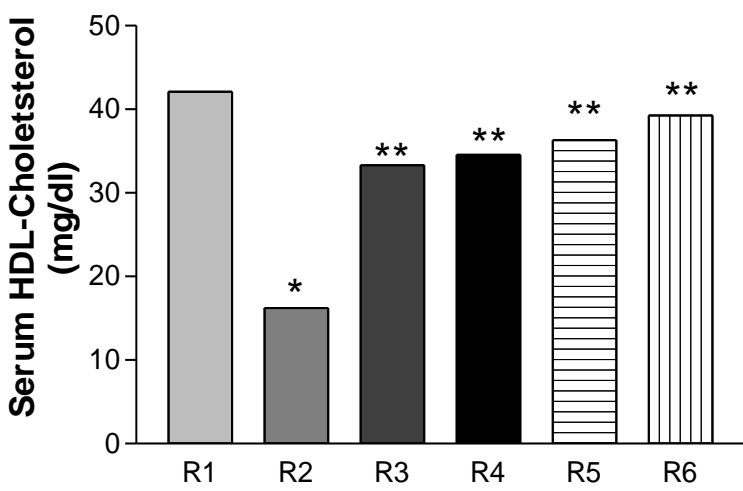

Figure 3: Effect of Various Extracts of Cedrela toona Roxb. On Serum HDL Cholesterol levels

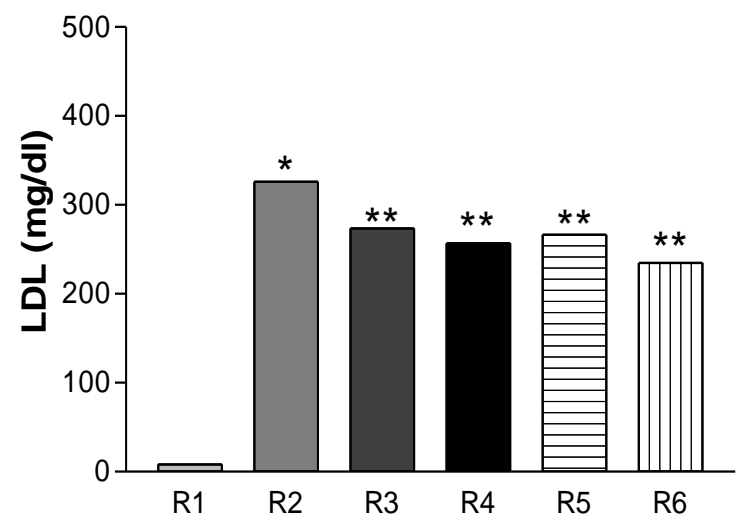

Figure 4: Effect of Various Extracts of Cedrela toona Roxb. On Serum LDL levels

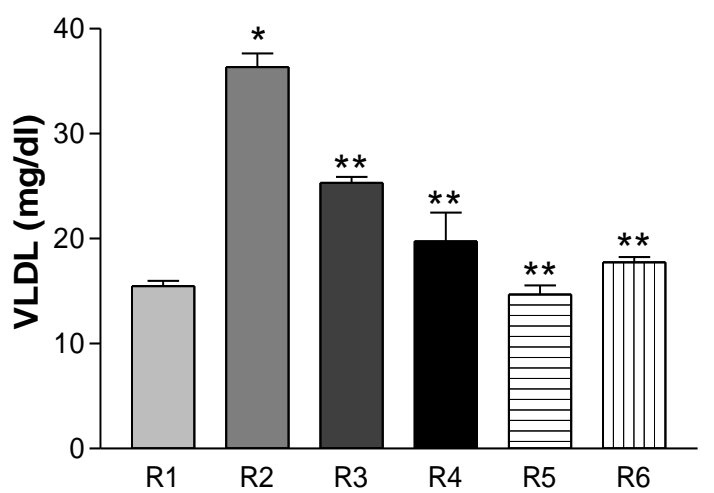

Figure 5: Effect Various Extracts of Cedrela toona Roxb. On Serum VLDL levels 


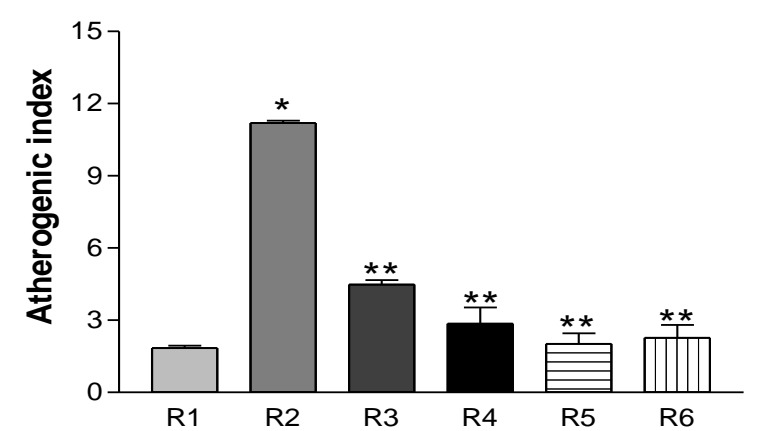

Figure 6: Effect of Various Extracts of Cedrela toona Roxb. On Atherogenic index

\section{CONCLUSION}

The present study suggested that the methanolic extract of Cedrela toona fruit possesses antihyperlipidaemic activity and therefore further studies can be taken up for drug discovery.

\section{REFERENCES}

1. Khare, C.P. Indian Medicinal Plant. An Illustrated Dictionary. Published by Springer, 2006,112 -113.

2. Loupee D, Oteng- Amoaka A.A, Brink M. Timber 1. Vol1, vol7, PROTA publishers, 2008,557-559.

3. http://en.wikipedia.org/wiki/Toon

4. Kashyapa K, Chand R. The useful plants of India. National Institute of Sciences Communication and Information Resources, New Delhi,2006,112-113.

5. Nadkarni A K. Indian Materia Medica. Edn 3, Vol I, Popular prakashan, 2009, 1908.

6. Pullaiah , T. Biodiversity in India. Vol 4, Published by Regency Publication ,2006,160.

7. Warrier P.K, Nambiar V P K. Indian Medicinal Plant: a compendium of 500 species.Vol 5, Orient Langman Priceate, 1996, 294.

8. Kiritikar K.R, Basu B.D, Indian Medicinal Plants. International Book distributors, Dehradhun 248 001,1995,562.

9. Hodges R, McGeachin, S.G, Raphael R.A. The chemistry of cedrelone. J Chem Soc 1963;p.2515-2526. DOI: 10.1039/JR9630002515

10. Karus W, Bauman S, Bokel M, Cramer R, Grimminger W, Handlmeir R, Keil E, Keller A, Klingele M, Pohnl H, Schwinger M. In: Proceeding of the $1^{\text {st }}$ Princess Chulabhorn Sciences Congress, 1 st Congress on Natural Products Bangkok Vol 2, 1987,554.

11. Gopalakrishnan G, Singh N D P, Kasinath V, Rajan S S, Malathi R. Photooxidation of cedrelone, a tetratriterpenoids from Toona ciliata. Photochem Photobio 2000;72(4):464- 466.

12. Chowdhary R, Rashid R B, Sohrab M H, Hasan C M. 12alpha hydroxystigmast-4-en-3-one: a new bioactive steroid from Toona ciliate (Meliaceae). Pharmazie 2003;58:272-273.

13. Chaudhary R. 5- Methylcoumarins from Toona ciliata stem bark and their chemotaxonomic significance. Biochem Sys Eco 2004;32:103105.

14. Lio S-G, Yang S-P, Yuan T, Zhang C-R, Chen H-D, Wu Y, Xu Y-K and Yue J-M. Limonoids from the Leaves and Stems of Toona ciliata. J Nat Prod 2007;70:1268-1273.

15. Veiga TA, Gonzalez-Vazquez R, Neto JO, Silva MF, King-Diaz B, Lotina-Hennsen B. Siderin from Toona ciliata (Meliaceae) as photosystem II inhibitor on spinach thylakoids. Arch Biochem Biophys 2007;465(1):38-43.

16. Karus W, Grimminger W. Toonafolin, a novel tetranortriterpenoids B- lactone from Toona ciliata M.J.Roem. Var. australis (Meliaceae) Ann. Chem. 1981;1838-1843.

17. Ning J, Di Y-T, Li S-F, Geng Z-L, HeH-P, Wang Y-H, Wang Y-Y, Li Y, Li S-L, Hao X-L. Polyynes from Toona ciliate var. ciliata and related Cytotoxicity Activity. Helv Chim Acta 2011;94:376-381.

18. Li J Z, Mo H N, Ning X M. Study on chemical constituents of tree of Toona ciliata. Zhong Yao Cai 2009;32(10):1539-1542.

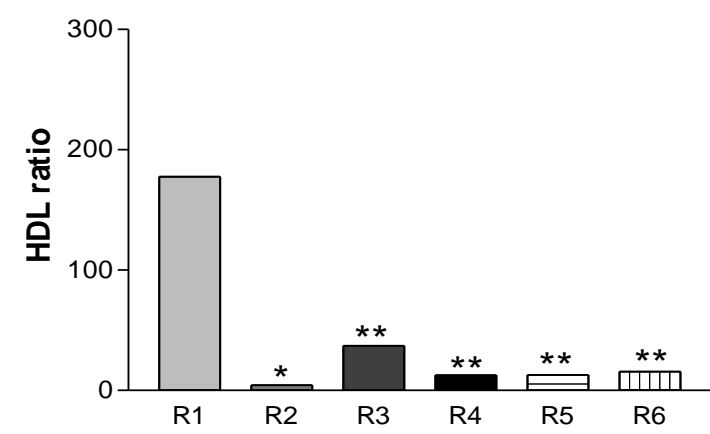

Figure 7: Effect of Various Extracts of Cedrela toona Roxb. On HDL Ratio

\section{ACKNOWLEDGEMENT}

The authors are thankful to Dr. S. S. Pandya, Principle, B. Pharmacy College, Rampura - Kakanpur for providing infrastructural facilities for this work.

19. Gambo-Castro I, Das M F, Silva D, Fo E R, Fernades J B, Vieira P C, Pinheiro A L. Unusual natural 9,10-dihydrophenthrenes from roots of Toona ciliata. ARKIVOC 2004;4:45-53.

20. Ning J, He H-P, Li S-F, Geng Z-L, Fang X, Di Y-I, Li S-L, Hao XJ. Triterpenoids from leaves of Toona ciliata. J Asian Nat Prod Res 2010;12(6):448-452.

21. Seifried HE, Anderson DE, Fisher EI, Milner JA. A review of the interaction among dietary antioxidants and reactive oxygen species. J Nutr Biochem 2007;18:567-79.

22. Diplock AT, Charleux JL, Crozier- Willi G, Kok FJ, Rice-Evans C, Roberfroid M, et al. Functional food science and defense agains reactive oxidative species. Br J Nutr 1998;80:S77- 112.

23. Maxwell S. Antioxidant therapy: Does it have a role in the treatment of human disease? Expert opin Investig Drug 1997; 6(2):11-36.

24. Malairajan P, Gopalakrishnan G, Narasimhan S, Veni K J K, Kavimani S. Anti- ulcer activity of crude alcoholic extract of Toona ciliata Roemer (heart wood). J Ethanopharmacol 2007;1 10:348-351.

25. Malairajan P, Gopalakrishnan G, Narasimhan S, Veni K J K. Analgesic activity of some Indian medicinal plants. J Ethanopharmacol 2006;106:425-428.

26. Govindachari T R, Suresh G, Gopalakrishnan G, Masilamani S Banumathi B. Antifungal activity of some tetratriterpenoids. Fitoterpia 2000;71:317-320

27. Chowdhary R, Hasan C M, Rashid M A. Antimicrobial activity of Toona Ciliata and Amoora rohituka. Fitoterpia 2003;74:155-158.

28. Bibi Y, Nisa N, Chaudhary F M, Zia M. Antibacterial activity of some selected medicinal plants of Pakistan. BMC Complementary and Alternative Medicine 2011, 11:52.

29. Chowdhary R, Hasan C M, Rashid M A. Bioactivity from Toona ciliata Stem Bark. Pharmaceutical Bio 2003;41(4):281- 283.

30. Harbone JB, Phytochemical Methods: A guide to modern techniques of plant analysis, $3^{\text {rd }}$ Edition, Chapman and Hall, London, 1998

31. PHS (Public Health Service) Policy on Human Care and Use of laboratory animals, available from office for protection from research risks, Washington DC, U S Department of health Survice(Bethesda, NIII), 1986 .

32. Modi KP, Vishwakarma SL, Goyal RK and Bhatt PA Hypolipidemic and Antioxidant Activity of Coenzyme Q10 in high cholesterol fed diet rats, Current Pharma Research Journal, 2007, 01(06); 31-35.

33. Pandya N, Santani D, Jain S, Antioxidant activity of ezetimibe in hypercholesterolemic rats, Indian J Pharmacol, 2006, 38(3); 205 , 206.

34. Ajay Gautam, Deenanath Jhade, Dheeraj Ahirwar, Manish Sujane, Ganesh N.Sharma, Pharmacognostic evaluation of Toona ciliata Bark. J. Adv. Pharm. Tech. Res. 2010:1(2); 216-220. 